\title{
Supernumerary chromosomes on Southern European populations of the cockle Cerastoderma edule: Consequence of environmental pollution?
}

\author{
Alexandra Leitã o a, b, *, Raquel Chaves ${ }^{\mathbf{a}}$, Sandra Joaquim ${ }^{\mathbf{b}}$, Domitília Matias ${ }^{\mathbf{b}}$, Francisco \\ Ruano ${ }^{c}$, Henrique Guedes-Pinto ${ }^{a}$
}

a Department of Genetics and Biotechnology, Centre of Genetics and Biotechnology of the University of Trá s-os-Montes and Alto Douro CGB/UTAD P-5000-911 Vila Real, Portugal

b INRB, I.P./IPIMAR, Avenida 5 de Outubro, 8700-305 Olhão, Portugal

c INRB, I.P./IPIMAR Avenida de Brasília, 1449-006 Lisboa, Portugal

Keywords:

Cerastoderma edule

chromosomal

abnormalities

environmental

adversity fission

in situ restriction enzyme

banding oil spill

\begin{abstract}
A b s t r a c t
Cerastoderma edule (Cardiidae) has a diploid chromosome number of 2n 1/4 38, its karyotype consisting of 12 submetacentric, 4 subtelocentric and 3 telocentric chromosome pairs. Hyperdiploid cells had pre- viously been observed in two populations of the Northern Galician coasts (northwest of Spain). The supernumerary chromosomes being easily distinguished by their reduced differentiated size and by their intra- and inter-individual variability. After the recent observation of $35 \%$ of cells with supernumerary chromosomes in a population of the Southern Galician coasts (Vigo) and 15\% of cells with supernumerary chromosomes in a population of the south of Portugal (Ria Formosa, Algarve), we attempted, in this paper, an elucidation of the nature of these supernumerary chromosomes, by differential banding technique with restriction enzymes on these hyperdiploid cells. Analysis of the restriction enzyme banding of the $2 n>38$ karyotypes led us to propose the occurrence of a chromosomal fission event involving the largest submetacentric chromosome pair. This study represents the first description of the occurrence of a possible chromosomal fission in marine bivalves. Different levels of environmental pollution are suggested as possible explanation for the differences observed on the proportion of hyperdiploid cells between the Southern Portugal population and the three Galicianones.
\end{abstract}

\section{Introduction}

A chromosome complement of 2 n $1 / 438$ has been reported for Cerastoderma edule (Cardiidae) (Insua and Thiriot-Quié vreux, 1992; Koulman and Wolff, 1977), standard karyotype consisting of 12 submetacentric, 4 subtelocentric and 3 telocentric chromosomal pairs (Insua and Thiriot-Quié vreux, 1992). Five chromosomal pairs are carriers of a cluster of 5S rDNA at the telomeres of the long arm (Insua et al., 1999).

However, in Insua and Thiriot-Quié vreux (1992) observed the presence of 1-3 supernumerary chromosomes in addition to those of the standard complement in 43\% (15 cells out of 35) in one Northern Galician (northwest of Spain) population (Baldayo). They were easily distinguished by their reduced differentiated size, which was much smaller than that of the smallest chromosomal pairs of the standard complement. In another Northern Galician

\footnotetext{
* Corresponding author. INRB, I.P./IPIMAR, Avenida 5 de Outubro, 8700-305 Olhão, Portugal.

E-mail address: aleitao@ipimar.pt (A. Leitão).
}

population (Ria del Pasaje), the same authors (unpublished data), observed 153 metaphases (taken from 10 animals), and identified in 57 cells $(37 \%)$ what that they presumed to be B chromosomes. Recently, during a restriction enzyme banding study (Leitã o et al., 2006) of two veneroid bivalves including this species, made by our group, we also noticed (unpublished data) the occurrence of hyperdiploid cells $(2 n>38)$ in a population of the south of Portugal (Ria Formosa, Algarve) and in a population of the Southern Galician Coasts (Vigo).

Supernumerary chromosomes, also called accessory or B chromosomes in order to distinguish them from the standard A chromosomes (normal diploid complement), were first detected by Wilson (1906) in the karyotype of a hemipteran insect. B chromosomes can be originated intraspecifically from the standard A complement or interspecifically as a result of interspecies mating (Camacho et al., 2000). B chromosomes could either be a byproduct of chromosomal rearrangements or a by-product of in- jured chromosomes. Until recent years, most supernumerary chromosomes went unclassified because their small size did not allow their identification using banding techniques. However, in humans, the combination of banding methods, has allowed their complete identification in most cases, since almost all of the 
were derived from A chromosomes (Fuster et al., 2004). Among Crustacean Decapoda, numerical chromosome variability is frequent, and it has been hypothesised that the presence of supernumerary chromosomes account for this variability. Thanks to the improvement of cytogenetic analysis by chromosomal banding, supernumerary B chromosomes have been demonstrated in Nephrops norvegicus, Homarus americanus, Palinurus elephas and Palinurus mauritanicus, belonging to several different families (Collucia et al., 2004). In all four species Chromosomes B were variable in number, mainly heterochromatic and undigested by various endonucleases. In the catfish, Iheringichthys labrosus, B microchromosomes appeared totally heterochromatic and were not digested by two different restriction endonucleases (Carvalho and Dias, 2005).

In marine bivalves, besides the previously mentioned study by Insua and Thiriot-Quié vreux (1992), supernumerary chromosomes have also been observed in a variable number on several strains of the bivalve genus Lasaea (e.g. O'Foighil and Thiriot-Quié vreux, 1991) where odd ploidy numbers were also observed and in Sphaerium corneum (Petkeviciute et al., 2006). In the last case, B chromosomes were one of the causes of observed inter- and intra- individual variation in the diploid chromosome number. Characterization of the supernumerary chromosomes observed by Insua and ThiriotQuiévreux (1992 and unpublished) was never performed. One of the main problems that might have prevented a better understanding of this phenomenon (and also can explain the limited studies existing in chromosomes of Cerastoderma edule or other veneroid bivalves) was the difficulty to get good quality banding patterns in chromosomes of this species. In situ digestion with restriction endonucleases (REs), which cleave DNA at specific target sequences, has been shown to produce consistent banding patterns, for instance, in fixed mammalian (e.g. Chaves et al., 2002), fishes (e.g. Carvalho and Dias, 2005) and insect chromosomes (e.g. Marchi and Mezzanote, 1988). In bivalves it has already been successfully applied to mussels (Martinez-Lage et al., 1994), scallops (Gajardo et al., 2002), oysters (Leitã o et al., 2004; Bouilly et al., 2005; Cross et al., 2005) and more recently to two species of veneroids, the clam Ruditapes decussatus and the cockle C. edule (Leitã o et al., 2006). In all cases, specific chromosome bands were obtained after digestion with REs, allowing the unambiguous identification of all chromosome pairs as well as the establishment of precise karyotypes.

Hence, in this study, we applied the restriction enzyme banding technique in order to try to characterize the hyperdiploid metaphases of Cerastoderma edule.

\section{Material and methods}

\subsection{Biological material}

Fifteen specimens of Cerastoderma edule were intertidally collected at Almargem (Ria Formosa lagoon, Algarve, south of Portugal) and 15 at Isla de San Simón (Baia de Vigo, south of Galicia, Spain). Before processing, the animals of both populations were acclimated at the IPIMAR-Tavira hatchery for 1 week..

\subsection{Chromosome preparation}

Whole juvenile animals (ca. $1.5 \mathrm{~cm}$ length) were incubated for 7 $\mathrm{h}$ in a $0.005 \%$ solution of colchicine in seawater. Then the gills were dissected and treated for $30 \mathrm{~min}$ in $0.9 \%$ sodium citrate in distilled water. The material was fixed in a freshly prepared mixture of absolute alcohol and acetic acid (3:1) with three changes of 20 min each. Fixed pieces of gill from each individual were dissociated in 50\% acetic acid with distilled water solution. Slides were prepared following and air-drying technique (Thiriot-Quiévreux and Ayraud, 1982). The slides were kept at $20 \mathrm{C}$ until further used.

\subsection{In situ restriction endonuclease digestion}

Slides were aged during $6 \mathrm{~h}$, in a dry incubator at $65 \mathrm{C}$, before the restriction endonuclease treatment. The restriction enzyme used: HaeIII (GG/CC) was diluted in the buffer indicated by the manufacturer (Invitrogen, Life Technologies), and final concentrations of $30 \mathrm{U}$ were obtained per $100 \mathrm{ml}$ (following Leitã o et al., 2006). Then $100 \mathrm{ml}$ of this solution were placed on each slide and covered with coverslips. These slides were incubated in a humid chamber for $16 \mathrm{~h}$ at $37 \mathrm{C}$. The slides were then washed in distilled water, air dried and stained with Giemsa (1\% solution, diluted in phosphate buffer at $\mathrm{pH}$ 6.8).

\subsection{Microscopy and image processing}

Images of metaphases of Cerastoderma edule from both the Ria Formosa and the Vigo populations banded with the restriction endonuclease HaeIII were acquired with a CCD camera (Axiocam, ZEISS) coupled to a ZEISS Axioplan 2 Imaging microscope. Digitised photos were printed from Adobe Photoshop (version 5.0) using only contrast optimisation functions that affected the whole of the image.

\subsection{Karyotypes organization}

The karyotypes of the banded hyperdiploid metaphases were organized by relative length, centromeric position and also following the pattern of the HaeIII restriction enzyme banding established for Cerastoderma edule (Leitã o et al., 2006).

\section{Results}

In Fig. 1 are presented examples of a 2n $1 / 440$ hyperdiploid metaphase (Fig. 1a) and respective karyotype (Fig. 1b) of Cerastoderma edule banded with the RE HaeIII.

The analysis of the RE banding pattern of 81 metaphases of Cerastoderma edule from the south of Portugal population showed the presence of $15 \%$ (12 out of the 81 ) of hyperdiploid metaphases, observed in 8 of the 15 animals studied. These corresponded to 10 metaphases with $2 \mathrm{n} 1 / 440$ and 2 metaphases with 2 n $1 / 439$. The analysis of the REbanding pattern of 77 metaphases of $\mathrm{C}$. edule from the Vigo population (Southern Galician one) showed the presence of $35 \%$ (27 out of the 77) of hyperdiploid metaphases, observed in 11 of the 15 animals studied. These corresponded to 24 metaphases with $2 n^{1 / 4} 40$ and 3 metaphases with $2 n^{1 / 4} 39$. We did not observe any hyperdiploid metaphase with $2 \mathrm{n} 1 / 441$, as previously observed by Insua and Thiriot-Quiévreux (1992) study.

The analysis of the corresponded karyotypes suggested the presence of one rearrangement involving the largest submetacentric pair and the "supernumerary small chromosomes". Restriction enzyme banding pattern indicates that homology exists between the largest submetacentric chromosome pair number one and the small "supernumerary chromosomes" present in the hyperdiploids cells, more precisely between these last ones and the final/distal part of the short arm of the largest chromosomal pair number one as place in evidence in Fig. 2.

\section{Discussion}

The analysis of the hyperdiploid metaphases of the studied Southern European populations of Cerastoderma edule, banded with the restriction enzyme, led us to suggest the hypothesis of the occurrence of a fission event involving the largest submetacentric 
chromosome pair number one of the A chromosome set. Following this hypothesis the $2 \mathrm{n}>38$ metaphases should have originated from the $2 \mathrm{n}^{1 / 4} 38$ through chromosomal fission.

Karyological polymorphisms are often best explained by the fission theory even in non-mammalian animal taxa (Kolnicki, 2000). Feldberg et al. (2004) suggested as one of the possible scenarios for the origin of $\mathrm{B}$ chromosomes in Amazon cichlid species, chromosomal breakdowns, by lagging chromosome fragments during cell division. Chromosomal fission events have also already been suggested in marine invertebrate species. Dixon et al. (1994) proposed that the five pairs of metacentric chromosomes of the 2n 1/426 karyotype of the gastropod species Nucella lapillus con- tributed to the polymorphism of the $2 n>$ 26, through Robertsonian chromosomal fission event. Later Pascoe (2006), showed that the karyotype was not always the same for a given chromosome number, and that more than five pairs, mentioned in previous studies, were polymorphic in this species. This study is, however, to our knowledge the first description of the occurrence of a possible chromosomal fission in marine bivalves. Chromosomal fissions provide indeed a fertile playground of karyotypic and genetic var- iation for selection pressures to act upon. A meticulous analysis of individual chromosomal cases, using molecular cytogenetic tech- niques could elucidate the role of this phenomenon in karyotypic polymorphisms and evolution.

The discrepancy of the percentage of hyperdiploid cells ob- served between the Ria Formosa population with $15 \%$ and the 3 Galician populations with $35 \%, 37 \%$ and $43 \%$ could probably be due to: (a) interpopulation genetic variability among the different Cerastoderma edule populations, as found for instance, in different populations geographically distant of Pecten maximus (Heipel et al., 1998), Haliotis rubra (Huang et al., 2000) and Mytilus chilensis (Toro et al., 2004); (b) to the impact of different environmental conditions to which these populations have been subjected. There are not presently any comparative studies on population genetics in $\mathrm{C}$. edule. In order to check the last hypothesis on differential envi- ronmental impact, we searched for existing bibliographic data in order to examine if there were different levels of environmental adversity that could be the cause of this discrepancy. Ria Formosa is a shallow mesotidal lagoon located in a Natural park between land and open sea. Although subjected to high anthropogenic pressures derived from domestic sewage (major tourist area) and agriculture effluents, it has never suffered significant industrial impact or any oil spill. On the other hand the Galician coast has suffered several major oil spills in the last 30 years: in 1970 the Norwich tank "Polycommander'" with 50,000 tons of heavy fuel oils, in 1976 the Spanish "Unquiola" released into the "La Coruna' bay 100,000 tons of oil, in 1978 the Greek tank "Andros Patnia', released 50,000 tons, and in 1992 another Greek tank "Mar Egeu", created a massive marine pollution over more than $200 \mathrm{~km}$ of the Galician coast. And more recently, the "Prestige", oil spill in November 2002 that sunk $270 \mathrm{~km}$ of the Galician coast releasing 30,000 tons of oil.

Effects of pollutants are usually displayed first at the bio- chemical and molecular levels (Veldhuizen-Tsoerkan et al., 1991). This then leads to genetic changes that become cytological visible, especially in the tissues of organisms which are good pollutant bio accumulators, such as molluscs. A relationship has in fact been suggested between hyperdiploid metaphases and effects of envi- ronmental mutagenic factors, such as industrial pollution (Giagia et al., 1985).

Due to their sedentary character and relatively long life-span, benthic faunal organisms, specifically bivalves are relatively susceptible to environmental changes in the ecosystem which occur in space and over time (Sokolowski et al., 2004), which makes them suitable for studies on environmental pollution.
In a study by Baršiene (1994), in $80 \%$ of the bivalve specimens studied a positive correlation between heavy metal, aromatic hydrocarbon or radionuclide bioaccumulation and chromosome set disturbances was put in evidence. Exposure of mussels to environmental contamination gave rise to DNA damage comprising chromosomal aberrations (AlSabti and Kurelec, 1985), sisterchromatid exchange (Dixon et al., 1985), strand-breaks and cross links (Vukmirovic et al., 1994) and higher coefficient of variation (CV) in DNA fluorescence which is indicative of increased chromosomal damage (Bickman, 1990), and could be reflective of aneuploid mosaicism or of chromosomal fragmentation phenomena (Lowcock et al., 1997). Cytogenetic analysis showed the presence of disseminated neoplasia in gill tissue of the Baltic clam Macoma balthica, with high-accumulated tissue concentrations of trace metals (As, $\mathrm{Ag}, \mathrm{Cd}, \mathrm{Pb}, \mathrm{Cu}$ and $\mathrm{Zn}$ ) from the Gulf of Gdansk, Poland (Sokolowski et al., 2004). Pesticides like atrazine have also shown to have a significant impact by enhancing the aneuploidy level of the Pacific oyster Crassostrea gigas (Bouilly et al., 2003) and also the persistence of atrazine impact on the aneuploidy level in time, within and between generations of this oyster species (Bouilly et al., 2004).

In what specifically concerns pollution by oil spills, higher micronuclei frequencies were found in mussels collected on the Baltic Sea (Palanga) following an accidental oil spill in November 2001 (Baršiene_et al., 2004). More recently the release of polycyclic aromatic hydrocarbons into the marine environment after the "Erika" ship wreck along the coats of France, mussels (Mytilus sp.) were affected by the oil slick in various degrees (Lemiere et al., 2005).

We can then suggest, as a hypothesis, that the important differences on the proportion of hyperdiploid cells, cells with the occurrence of the fission event, between the Southern Portugal population and the Galician ones, could possibly be explained by the important pollution by polycyclic aromatic hydrocarbons due to several major oil spills suffered by the Galician populations. We believe that it would be interesting to develop an ecotoxicological study in order to test this hypothesis.

The fact that the Southern Portugal population, which has suffered pollution from agricultural effluents and domestic sewage, but has never suffered major industrial impact or oil spill, presents nevertheless $15 \%$ of cells with occurrence of the fission event on the distal part of the largest submetacentric chromosome short arm, could suggest that this chromosome site represents a "hotspot" for chromosome breakage on the karyotype of Cerastoderma edule. Hence, in a recent study, Webber and Ponting (2005) proposed the occurrence of "hotspots" of mutation and breakage in dog and human chromosomes.

The observation by Insua and Thiriot-Quie' vreux (1992) of sometimes hyperdiploid metaphases of 2 n $1 / 441$ (2n 1/4 38 p 3), which were not observed in this study, might suggest the possible existence of another "hotspot" for chromosome breakage on the karyotype of this species.

The results of this study could then sustain the use of cytogenetic damage in pollution control measurement studies, atypical cytogenetic features in bivalve species could be in this way con- sidered as alerting indicators of poor environment health.

\section{Acknowledgements}

This work was partially supported by a Portuguese grant from the Ministry of Science and Technology (FCT) (SFRH/BPD/18961/2004) and by the PROMAR Project (Interreg IIIA) and the "Tecno- logias de Produça 0 Aqui' cola" Project (22-05-01-FDR-0009 Mare). We are grateful to A. Conde for supplying live C. edule samples of the Vigo population, M. Matias and M. Teixeira for technical assis- tance and to A. Good for revising the English. 


\section{References}

AlSabti, K., Kurelec, B., 1985. Induction of chromosomal aberrations in the mussel Mytilus galloprovincialis watch. Bulletin of Environmental Contamination Toxicology 35, 660-665.

Baršiene, J., 1994. Chromosomeset changes in molluscs from highly polluted habitats. In: Beaumont, A.R. (Ed.), Genetics and Evolution of Aquatic Organisms. Chapman and Hall, London, pp. 434-447.

Baršiene, J., Lazutka, J., Syvokiene, J., Dedonyte, V., Rybakovas, A., Bagdonas, E., Bjornstand, A., Andersen, O.K., 2004. Analysis of micronuclei in blue mussels and fish from the Baltic and North Seas. Environmental Toxicology 19, $365-371$.

Bickman, J.W., 1990. Flow cytometry as a technique to monitor the effects of environmental genotoxins on wildlife populations. In: Sandhu, S., Lower, W.R., De Serres, F.J., Suk, W.A., Tice, R.R. (Eds.), In Situ Evaluation of Biological Hazards of Environmental Pollutants. Environmental Research Series, vol. 38. Plenum Press, New York, NY, USA, pp. 97-108.

Bouilly, K., Leitão, A., McCombie, H., Lapègue, S., 2003. Impact of atrazine on aneuploidy in Pacific oysters, Crassostrea gigas. Environmental Toxicology and Chemistry 22, 219-223.

Bouilly, K., McCombie, H., Leitão, A., Lapègue, S., 2004. Persistence of atrazine impact on aneuploidy in Pacific oysters, Crassostrea gigas. Marine Biology 145, 699-705.

Bouilly, K., Leitão, A., Chaves, R., Guedes-Pinto, H., Boudry, P., Lapègue, S., 2005. Endonuclease banding reveals that atrazine-induced aneuploidy resembles spontaneous chromosome loss in Crassostrea gigas. Genome 48, 177-180.

Camacho, J.P.M., Sharbel, T.F., Beukeboom, L.W., 2000. B chromosome evolution. Philosophical Transactions of the Royal Society of London, Series B 355, $163-178$.

Carvalho, R.A., Dias, A.L., 2005. Karyotypic characterization of Iheringichthys labrosus (Pisces, Pimelodidae): C-, G- and restriction endonuclease banding. Genetics and Molecular Research 4, 663-667.

Chaves, R., Adega, F., Santos, S., Heslop-Harrison, J.S., Guedes-Pinto, H., 2002. In situ hybridization and chromosome banding in mammalian species. Cytogenetic and Genome Research 96, 113-116.

Collucia, E., Cannas, R., Cau, A., Deiana, A.M., Salvadori, S., 2004. B chromosomes in Crustacea Decapoda. Cytogenetic and Genome Research 106, 215-221.

Cross, I., Díaz, E., Sá nchez, I., Rebordinos, L., 2005. Molecular and cytogenetic characterization of Crassostrea angulata chromosomes. Aquaculture 247, $135-144$.

Dixon, D.R., Jones, I.M., Harrison, F.L., 1985. Cytogenetic evidence of inducible pro- cesses linked with metabolism of a xenobiotic chemical in adult and larval Mytilus edulis. Science of the Total Environment 46, 1-8.

Dixon, D.R., Pascoe, P.L., Gibbs, P.E., Pasantes, J.J., 1994. The nature of Robertsonian chromosomal polymorphism in Nucella lapillus: a re-examination. In: Beaumont, A.R. (Ed.), Genetics and Evolution of Aquatic Organisms. Chapman and Hall, London,pp. 389-399.

Feldberg, E., Porto, J.I.R., Alves-Brinn, M.N., Mendonça, M.N.C., Benzaquem, D.C., 2004. B chromosomes in amazonian cichlid species. Cytogenetic and Genome Research 106, 195-198.

Fuster, C., Rigola, M.A., Egozcue, J., 2004. Human supernumeraries: are they B chromosomes? Cytogenetic and Genome Research 106, 165-172.

Gajardo, G., Parraguez, M., Colihueque, N., 2002. Karyotype analysis and chromosome banding of the Chilean-Peruvian ScallopArgopecten purpuratus. (Lamarck, 1819). Journal of Shellfish Research 21, 585-590.

Giagia, E., Soldatović, B., Savić , I., Zimonjić, D., 1985. Karyotype study of the genus Apodemus (Kaup, 1829) populations from the Balkan Peninsula. Acta Veterinaria (Beograd) 35, 289-298.

Heipel, D.A., Bishop, J.D., Brand, A.R., Thorpe, J.P., 1998. Population genetic differentiation of the great scallop Pecten maximus in western Britain investigated by randomly amplified polymorphism DNA. Marine Ecology Progress Series 162, $163-171$.

Huang, B.X., Peakall, R., Hanna, P.J., 2000. Analysis of genetic structure of blacklip abalone (Haliotis rubra) populations using RAPD, minisatellite and microsatellite markers. Marine Biology 136, 207-216.
Insua, A., Thiriot-Quiévreux, C., 1992. Karyotypes of the Cerastoderma edule, Venerupis pullastra and Venerupis rhomboides (Bivalvia, Veneroida). Aquatic Living Resources 5, 1-18.

Insua, A., Freire, R., Mendez, J., 1999. The 5S rDNA of the bivalveCerastoderma edule nucleotide sequence of the repeat unit and chromosomal location relative to 18S-28S rDNA. Genetic Selection Evolution 31, 509-518.

Kolnicki, R.L., 2000. Kinetochore reproduction in animal evolution: cell biological explanation of karyotypic fission theory. Proceedings of National Academy of Sciences of the United States of America 97, 9493-9497.

Koulman, J.G., Wolff, W.S., 1977. The Mollusca of the estuarine regions of the rivers Rhine, Meuse and Schedt in relation to hydrographic of the area. V. The Cardiidae. Basteria 41,21-32.

Leitão, A., Chaves, R., Santos, S., Guedes-Pinto, H., Boudry, P., 2004. Restriction enzyme digestion chromosome banding in Crassostrea and Ostrea species: comparative karyological analysis within Ostreidae. Genome 47,781-788.

Leitão, A., Chaves, R., Matias, D., Joaquim, S., Ruano, F., Guedes-Pinto, H., 2006. Restriction enzyme digestion chromosome banding on two commercially important veneroid bivalve species: Ruditapes decussatus and Cerastoderma edule. Journal of Shellfish Research 25, 857-864.

Lemiere, S., Cossu-Leguille, C., Bispo, A., Jourdain, M.J., Lanhers, M.C., Burnel, D., Vasseu, P., 2005. DNA damage measured by the single-cell gel electrophoresis (COMET) assay in mammals fed with mussels contaminated by the "Erika" oilspill. Mutation Research 581, 11-21.

Lowcock, L.A., Sharbel, T.F., Bonin, J., Oullet, M., Rodrigue, J., DesGranges, J.L., 1997. Flow citometry assay for in vivo genotoxic effects of pesticides in Green frogs (Rana clamintas). Aquatic Toxicology 30, 241-255.

Marchi, A., Mezzanote, R., 1988. Restriction endonuclease digestion and chromosome banding in the mosquito, Culiseta longiareolata (Diptera: Culicidae). Heredity $60,21-26$

Martinez-Lage, A., Gonzalez-Tizon, A., Mendez, J., 1994. Characterization of different chromatin types in Mytilus galloprovincialis L. after C-banding, fluorochrome and restriction endonuclease treatments. Heredity 72, 242-249.

O’Foighil, D., Thiriot-Quiévreux, C., 1991. Ploidy and Pronuclear interaction in Northeastern Pacific Lasaeaclones (Mollusca: Bivalvia). Biological Bulletin 181, 222-231.

Pascoe, P.L., 2006. Chromosomal polymorphism in the Atlantic dog-whelk, Nucella lapillus (Gastropoda: Muricidae): nomenclature, variation and biogeography. Biological Journal of the Linnean Society 87, 195-210.

Petkeviciute, R., Stunzenas, V.A., Staneviciute, G., 2006. Polymorphism of the Sphaerium corneum (Bivalvia, Veneroida, Sphaeriidae) revealed by cytogenetic and sequence comparison. Biological Journal of the Linnean Society 89 (1), 53-64.

Sokolowski, A., Wolowicz, M., Hummel, H., Smolarz-Gorska, K., Fichet, D., Radenac, G. Thiriot-Quié vreux, C., Namiesnik, J., 2004. Abnormal features of Macoma balthica (Bivalvia) in the Baltic Sea: alerting symptoms of environ- mental adversity? Marine Pollution Bulletin 49 (1-2), 17-22.

Thiriot-Quiévreux, C., Ayraud, N., 1982. Les caryotypes de quelques espèces de bivalves et gastéropodes marins. Marine Biology 70, 165-175.

Toro, J.E., Ojeda, J.A., Vergara, A.M., 2004. The genetic structure of Mytilus chilensis (Hupe 1854) populations along the Chilean coast based on RAPDs analysis. Aquaculture Research 35, 1466-1471.

Veldhuizen-Tsoerkan, M.B., Holwerda, D.A., de Bont, A.M., Smaal, A.C., Zandee, D.I. 1991. A field study on stress indices in the sea mussel, Mytilus edulis: application of the "stress approach" in bio monitoring. Archives of Environmental Contamination and Toxicology 21, 297-304.

Vukmirovic, M., Bihari, N., Zahnm, R.K., Müller, W.E.G., Batel, R., 1994. DNA damage in marine mussels Mytilus galloprovincialis as a biomarker of environmenta contamination. Marine Ecology Progress Series 109, 165-171.

Webber, C., Ponting, C.P., 2005. Hotspots of mutation and breakage in dog and human chromosomes. Genome Research 15 (12), 1787-1797.

Wilson, E., 1906. Studies on chromosomes. V. The chromosomes of Metapodius. A contribution to the hypothesis of the genetic continuity of chromosomes. Journal of Experimental Zoology 6, 147-205. 


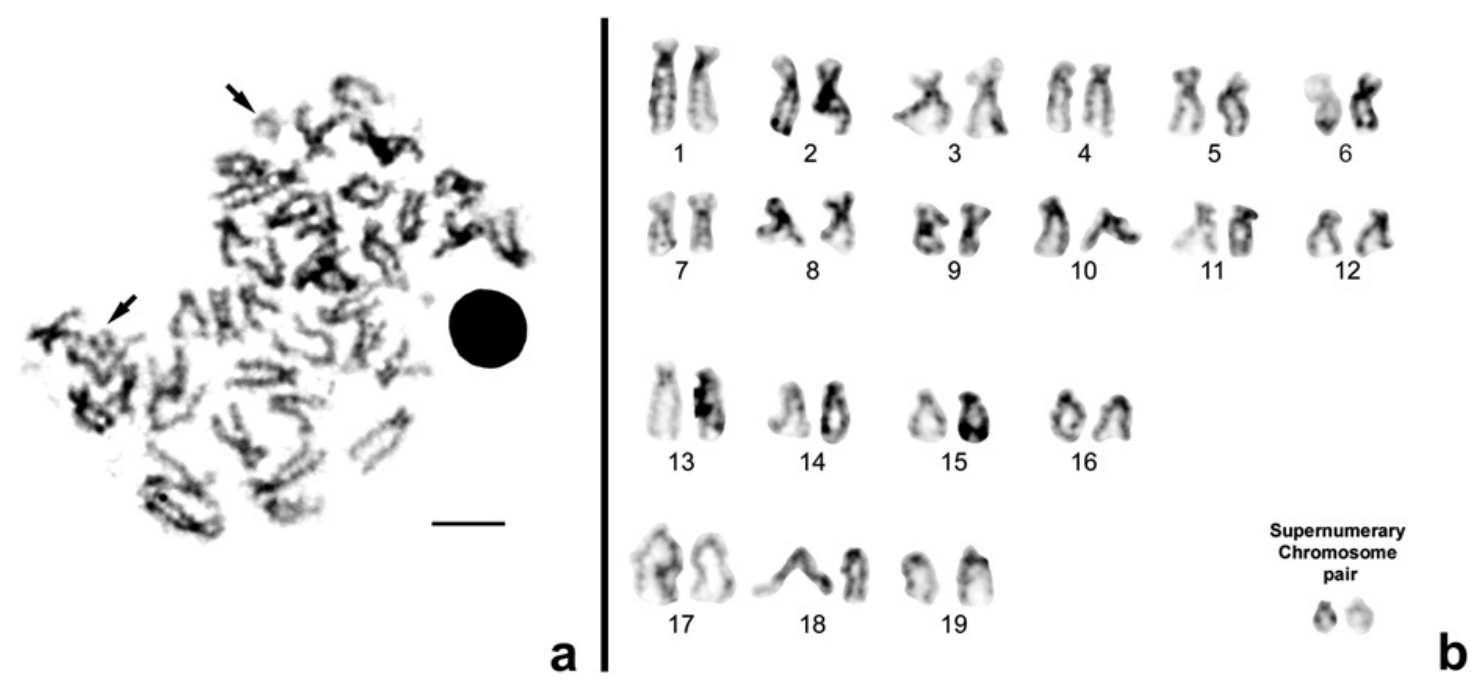

Fig. 1. Examples of a $2 \mathrm{n} 1 / 440$ hyperdiploid C. edule metaphase (a) and respective karyotype (b) banded with the RE HaeIII. Arrows indicate the "supernumerary chromosomes". Scale bar $1 / 45 \mathrm{~mm}$.

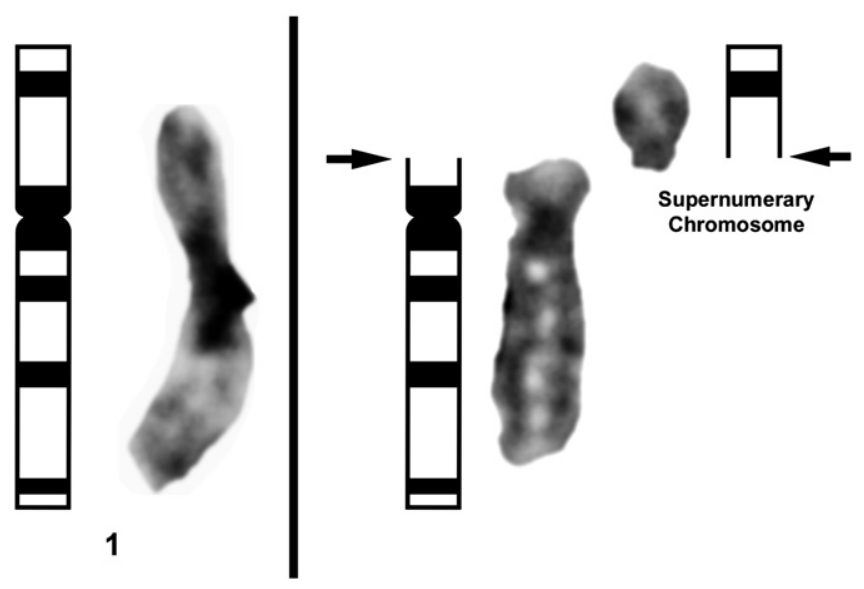

Fig. 2. Detail of the largest submetacentric chromosome pair number one from a $2 \mathrm{n} 1 / 438$ (left) restriction enzyme banded karyotype and from the $2 n 1 / 440$ (right) restriction enzyme banded karyotype of Fig. 1b. To put in evidence the banding ho- mology of the final/distal part of the short arm of the largest submetacentric pair number one and the "supernumerary" small chromosome pair, supporting the chro- mosomal fission hypothesis. 